\title{
Pengujian Model Kepatuhan Pajak Sukarela Pada Wajib Pajak Orang Pribadi di Kantor Pelayanan Pajak Pratama Manado
}

\section{DODY RADITYO ${ }^{1}$, LINTJE KALANGI $^{2}$, HENDRIK GAMALIEL $^{3}$}

\author{
1,2,3 Program Studi Magister Akuntansi, Fakultas Ekonomi dan Bisnis Universitas Sam Ratulangi \\ email: dody.radityo@gmail.com, lintje_kalangi@yahoo.com, hendrik_gamaliel@unsrat.ac.id
}

\begin{abstract}
The objective of this research is to test voluntary tax compliance model for individual taxpayers developed by Ratmono (2014) and attain an empirical evidence about the influence of tax sanctions and procedural fairness on trust in tax authority procedural fairness on trust in tax authority, the influence of trust in tax authority on voluntary tax compliance, and the mediating role of trust in tax authority in the effect of tax sanctions and procedural fairness on voluntary tax compliance. Data were collected by questionnaires. 106 questionnaires in total were used in the analysis, conducted with Structural Equation Modelling. The result has shown that procedural fairness is related to trust in tax authority. This research also supports the notion that trust in authority affects positively voluntary tax compliance. Trust in tax authority forms an important mediating variable to the procedural fairness in oder to enhance voluntary tax compliance.
\end{abstract}

Keywords: voluntary tax compliance, tax sanctions, procedural fairness, trust in tax authority.

Abstrak. Penelitian ini bertujuan menguji model kepatuhan pajak sukarela bagi wajib pajak orang pribadi yang dikembangkan Ratmono (2014) dan untuk mendapatkan bukti empiris mengenai pengaruh denda pajak dan keadilan prosedural terhadap kepercayaan pada otoritas pajak, pengaruh kepercayaan pada otoritas pajak terhadap kepatuhan pajak sukarela, serta peran kepercayaan pada otoritas pajak dalam memediasi pengaruh denda pajak dan keadilan prosedural terhadap kepatuhan pajak sukarela. Pengumpulan data dalam penelitian ini menggunakan kuesioner. Sebanyak 106 digunakan dalam proses analisis menggunakan Structural Equation Modelling. Hasil penelitian menunjukkan bahwa keadilan prosedural terkait dengan kepercayaan pada otoritas pajak. Penelitian ini juga memberikan bukti empiris bahwa kepercayaan pada otoritas pajak terkait dengan kepatuhan pajak sukarela. Kepercayaan pada otoritas pajak merupakan sebuah pemediasi penting pada keadilan prosedural sebagai sarana meningkatkan kepatuhan pajak sukarela.

Kata kunci: kepatuhan pajak sukarela, sanksi pajak, keadilan prosedural, kepercayaan pada otoritas pajak.

\section{Pendahuluan}

Penerimaan pajak merupakan sumber pendapatan terbesar dalam struktur Anggaran Pendapatan dan Belanja Negara (APBN). Sebagai sumber penerimaan dalam negeri, kegagalan untuk mencapai penerimaan pajak yang ditargetkan berdampak pada meningkatnya sumber pendapatan lain. KPP Pratama Manado merupakan institusi vertikal di bawah DJP yang bertugas menghimpun penerimaan pajak dengan wilayah kerja Kota Manado dan Kota Tomohon. Dalam beberapa tahun terakhir, KPP Pratama Manado tidak berhasil mencapai penerimaan pajak yang ditargetkan. Tidak tercapainya target penerimaan (shortfall) KPP Pratama Manado memberikan kontribusi pada meningkatnya sumber pendapatan/ pembiayaan lain yang mengganggu kemandirian bangsa. Tax ratio KPP Pratama Manado berada pada kisaran 6\%, lebih rendah dibandingkan dengan tax ratio nasional yang berada pada kisaran 
11\%. Kesenjangan (tax gap) sebesar 5\% tersebut merupakan sesuatu yang harus ditutup dengan kerja keras. Terlebih jika harus mencapai tax ratio sebesar $15-16 \%$ sebagaimana dikehendaki oleh Presiden Joko Widodo.

Tax gap tersebut disebabkan pertumbuhan ekonomi masyarakat sebagaimana tercermin dalam PDRB tidak diiringi pertumbuhan penerimaan pajak yang sepadan. Mengingat sistem perpajakan yang berlaku di Indonesia adalah self assessment yang memberikan kepercayaan kepada wajib pajak untuk menghitung/ memperhitungkan, membayar, dan melaporkan sendiri jumlah pajak yang seharusnya terutang, maka permasalahan penerimaan pajak sangat terkait erat dengan kepatuhan wajib pajak.

Kogler, Batrancea, Nichita, Pantya, Belianin dan Kirchler (2013) menyatakan bahwa tax ratio yang tinggi hanya dapat dicapai jika telah ada kepatuhan sukarela. Artinya upaya untuk meningkatkan tax ratio dapat dimulai dengan meningkatkan kepatuhan sukarela wajib pajak. Salah satu teori terkini tentang kepatuhan pajak adalah slippery slope model dari Kirchler, Hoelzl dan Wahl (2008). Teori ini menyatakan bahwa variabel-variabel psikologi sosial dan deterrence berpengaruh positif terhadap kepatuhan pajak. Variabel psikologi sosial cenderung mempengaruhi kepatuhan pajak sukarela (voluntary tax compliance) sedangkan variabel deterrence cenderung mempengaruhi kepatuhan pajak berdasarkan ketakutan akan konsekuensi negatif (kepatuhan pajak yang dipaksakan/ enforced tax compliance). Teori slippery slope ini menyatakan bahwa kebijakan peningkatan kepercayaan masyarakat pada otoritas pajak harus diutamakan dalam rangka meningkatkan kepatuhan pajak sukarela.

Berdasarkan teori slippery slope, Ratmono (2014) mengembangkan Model Kepatuhan Pajak Sukarela. Model tersebut melibatkan denda pajak dan sebagai variabel independen dan kepatuhan pajak sukarela sebagai variabel dependen dengan kepercayaan pada otoritas pajak sebagai variabel pemediasi, dengan keadilan prosedural ditempatkan sebagai variabel pemoderasi antara denda pajak dan kepatuhan sukarela wajib pajak.

Berdasarkan hasil tersebut di atas, penelitian ini bertujuan untuk melakukan pengujian model kepatuhan pajak sukarela yang dikembangkan oleh Ratmono (2014) setelah dilakukan respesifikasi model pada wajib pajak orang pribadi yang terdaftar di KPP Pratama Manado. Berdasarkan latar belakang tersebut masalah yang diteliti dalam penelitian ini dapat dirumuskan dalam bentuk beberapa pertanyaan penelitian sebagai berikut:

a. Apakah terdapat pengaruh positif Denda Pajak terhadap Kepercayaan pada Otoritas Pajak?

b. Apakah terdapat pengaruh positif Keadilan Prosedural terhadap Kepercayaan pada Otoritas Pajak?

c. Apakah terdapat pengaruh positif Kepercayaan pada Otoritas Pajak terhadap Kepatuhan Pajak Sukarela?

d. Apakah terdapat pengaruh positif Denda Pajak terdahap Kepatuhan Pajak Sukarela?

e. Apakah terdapat pengaruh positif Keadilan Prosedural terhadap Kepatuhan Pajak Sukarela?

f. Apakah terdapat pengaruh positif Denda Pajak terdahap Kepatuhan Pajak Sukarela dengan Kepercayaan pada Otoritas Pajak sebagai Variabel Pemediasi?

g. Apakah terdapat pengaruh positif Keadilan Prosedural terhadap Kepatuhan Pajak Sukarela dengan Kepercayaan pada Otoritas Pajak sebagai Variabel Pemediasi?

Tujuan yang ingin dicapai dalam penelitian ini adalah menguji dan memperoleh hasil empiris semua rumusan masalah. Penelitian ini diharapkan dapat memberikan validasi Model Kepatuhan Pajak Sukarela secara empiris. Selain itu penelitian ini diharapkan dapat dipergunakan sebagai bahan pertimbangan dan masukan bagi pengambil kebijakan dalam mengatasi masalah kepatuhan pajak yang dialami KPP Pratama Manado.Bagi akademisi, penelitian ini diharapkan dapat menambah referensi dan mendorong dilakukannya penelitianpenelitian lanjutan. 


\section{Tinjauan Pustaka}

\section{Slippery Slope Theory}

Slippery Slope Theory dikemukakan oleh Kirchler et al (2008), bertitik tolak dari pemahaman bahwa kepatuhan pajak (tax compliance) dilandasi oleh dua motif. Pertama, wajib pajak menjadi patuh karena mengkalkulasi bahwa biaya ketidakpatuhan lebih mahal. Selanjutnya, wajib pajak menjadi patuh karena merasa wajib untuk patuh sebagaimana yang dilakukan wajib pajak lain.

Berangkat dari kondisi di atas, Kirchler et al (2008) menggambarkan kepatuhan pajak dengan dua dimensi lain yaitu kewenangan otoritas pajak dan kepercayaan terhadap otoritas pajak. Kewenangan otoritas perpajakan dimaknai bahwa fiskus bertugas mendeteksi penghindaran pajak ilegal, antara lain melalui tindakan pemeriksaan dan memberikan sanksi kepada wajib pajak yang melakukan penghindaran. Sedangkan kepercayaan pada otoritas perpajakan digambarkan bahwa fiskus cenderung bersifat melayani dan memiliki itikad baik dalam melaksanakan pekerjaannya.

\section{Fairness Heuristic Theory}

Fairness Heuristic Theory yang dikemukakan Lind (2001) membahas bagaimana seseorang memutuskan jenis relasi dengan organisasi atau otoritas, ketika tidak tersedia informasi yang memadai. Teori ini menjelaskan apa yang mungkin menjadi dasar bagi seseorang apakah akan melibatkan diri lebih jauh dan tunduk pada otoritas atau memutuskan sebaliknya. Menurut teori ini, ketika seseorang tidak memperoleh informasi yang valid apakah otoritas baik dan dapat dipercaya, seseorang akan melakukan judgment berdasarkan keadilan prosedural. Artinya ketika otoritas dipandang berlaku adil terhadap semua, maka seseorang akan memutuskan untuk membangun relasi yang baik dengan otoritas tersebut, bahkan tunduk kepadanya.

\section{Denda Pajak}

Jatmiko (2006) menjelaskan sanksi merupakan suatu hukuman yang diberikan terhadap seseorang atau kelompok yang telah melanggar aturan yang telah dibuat atau disepakati, sedangkan denda merupakan salah satu di antara bentuk hukuman yang yang diberikan berupa membayar sejumlah uang dikarenakan seseorang atau kelompok tersebut telah melanggar peraturan yang berlaku dan disepakati (dalam Fajriyan et al, 2015). Pasal 8 Undang-undang Nomor 6 Tahun 1983 tentang Ketentuan Umum dan Tata Cara Perpajakan beserta perubahannya menjelaskan beberapa perbuatan wajib pajak yang dapat dikenakan sanksi, oleh karena itu sanksi termasuk denda menjadi suatu jaminan yang pasti agar peraturan dapat ditaati dan dipatuhi oleh wajib pajak. Dapat dikatakan bahwa denda sebagai salah satu bentuk sanksi adalah alat untuk membuat wajib pajak lebih mentaati dan mematuhi peraturan perpajakan yang telah ada.

\section{Keadilan Prosedural}

Ivancevich et al. (2006) menyebut keadilan prosedural merujuk pada keadilan yang dipersepsikan mengenai proses dan prosedur organisasi yang digunakan untuk membuat keputusan alokasi dan sumber daya (dalam Hakim et al 2017). Senada dengan hal tersebut, Tyler (1997) menyebutkan bahwa keadilan prosedural menunjukkan keadilan persepsian tentang prosedur yang digunakan untuk membuat keputusan alokasi.

\section{Kepercayaan pada Otoritas Perpajakan}

Robbin dan Judge (2007) mendefinisikan kepercayaan (trust) sebagai ekspektasi atau pengharapan positif bahwa orang lain tidak akan melalui kata-kata, tindakan dan kebijakan, 
bertindak secara opotunistik (dalam Hakim et al 2017). Kepercayaan melibatkan kesediaan seseorang untuk bertingkah laku tertentu karena keyakinan bahwa mitranya akan memberikan apa yang ia harapkan dan suatu harapan yang umumnya dimiliki seseorang bahwa kata, janji, atau pernyataan orang lain dapat diharapkan dan dapat dipercaya.

\section{Kepatuhan Pajak Sukarela}

Menurut Simanjuntak dan Mukhlis (2012) kepatuhan pajak sukarela (voluntary tax compliance) mencakup peningkatan kesadaran untuk tunduk terhadap peraturan perpajakan dan sekaligus terhadap administrasi pajak yang berlaku tanpa perlu disertai aktivitas tindakan dari otoritas pajak (dalam Hakim et al., 2017). Kastlunger et al. (2013) menyebut kepatuhan sukarela merupakan faktor penting dalam upaya meningkatkan penerimaan negara. Kepatuhan pajak sukarela (voluntary tax compliance) merupakan kepatuhan wajib pajak karena adanya kepercayaan wajib pajak pada otoritas pajak.

\section{Gambar 1 Model Kepatuhan Pajak Sukarela}

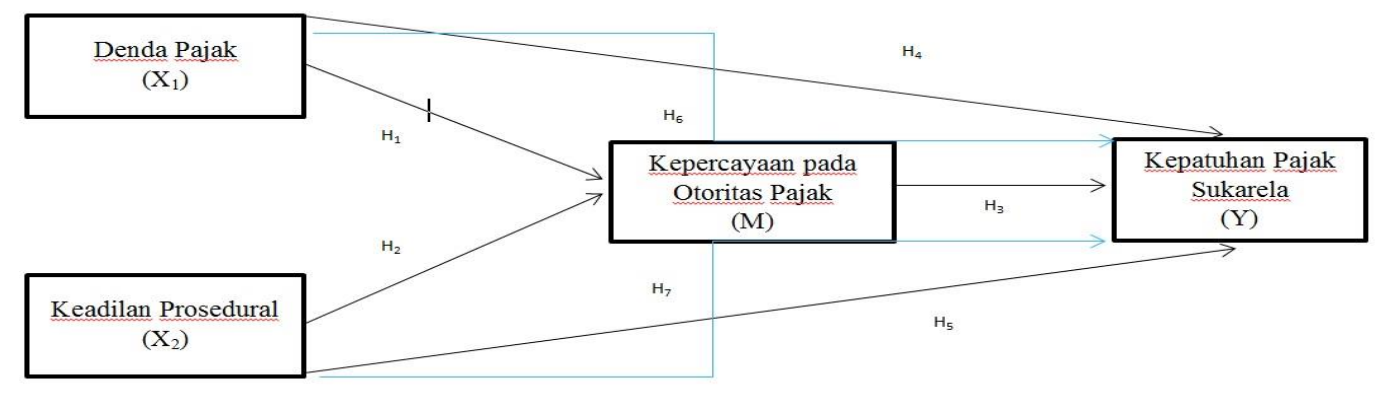

Berdasarkan landaran teori dan rerangka konseptual di atas, disusun persamaan sebagai berikut

Persamaan 1:

$M=\rho x 1 y \cdot X_{1}+\rho x 2 y \cdot X_{2}+\varepsilon 1$

Persamaan 2:

$Y=\rho x 1 y \cdot X_{1}+\rho x 2 y \cdot X_{2}+\rho$ my.M+ $\varepsilon 2$

di mana

$\mathrm{X}_{1}=$ Denda pajak

$\mathrm{X}_{2}=$ Keadilan prosedural

$\mathrm{M}=$ Kepercayaan pada otoritas pajak

$\mathrm{Y}=$ Kepatuhan pajak sukarela

$\varepsilon=\operatorname{error}($ nilai 0$)$

Selanjutnya dirumuskan hipotesis sebagai berikut :

\section{Pengaruh Denda Pajak terhadap Kepercayaan pada Otoritas Pajak}

Menurut teori slippery slope, denda dapat dipersepsikan sebagai balasan (retribution) yang tepat dari otoritas bagi perilaku yang membahayakan masyarakat. Denda karenanya dapat mempengaruhi kepercayaan pada otoritas. Denda yang tidak tepat misalnya, hanya karena seorang wajib pajak tidak sengaja membuat kesalahan yang disebabkan ketidakjelasan hukum pajak atau denda yang ringan untuk pelanggaran yang terlalu berat dapat menurunkan kepercayaan masyarakat terhadap otoritas. Pengaruh langsung antara denda pajak dan kepercayaan pada otoritas pajak telah terbukti berpengaruh signifikan sebagaimana hasil uji 
empiris yang dilakukan Ratmono (2014) yang membuktikan keberadaan denda pajak sekaligus merupakan bukti kehadiran sekaligus legitimasi otoritas pajak. Denda pajak merupakan sinyal ketidaksetujuan moral terhadap pelanggaran pajak. Sebaliknya, ketiadaan denda dapat dipersepsikan sebagai indikator bahwa otoritas pajak lemah sehingga menurunkan kepercayaan pembayar pajak yang jujur. Berdasarkan uraian di atas maka disusun hipotesis sebagai berikut:

\section{$\mathrm{H}_{1}$ : Denda Pajak berpengaruh positif terhadap Kepercayaan pada Otoritas Pajak}

\section{Pengaruh Keadilan Prosedural terhadap Kepercayaan pada Otoritas Pajak}

Fairness Heuristic Theory menjelaskan bahwa otoritas akan mendapat kepercayaan jika wajib pajak mempersepsikan otoritas pajak menerapkan prosedur yang adil. Setiap perlakukan tidak adil akan menimbulkan ketidakpercayaan terhadap otoritas pajak. Hasil studi empiris yang dilakukan Van Dijke dan Verboon (2010) menemukan bahwa terdapat pengaruh signifikan antara keadilan prosedural terhadap kepercayaan pada otoritas pajak. Hal ini sejalan dengan hasil penelitian Kastlunger et al. (2013) dan Ratmono (2014) yang mengkonfirmasi teori fairness heuristic. Prosedur dianggap lebih adil ketika wajib pajak memperoleh perlakuan yang sama dari otoritas pajak tanpa memperhatikan kepentingan. Keadilan tersebut dapat menciptakan kepercayaan pada otoritas pajak, dan sebaliknya ketidakadilan akan menyebabkan ketidakpercayaan, sehingga dirumuskan hipotesis sebagai berikut

$\mathrm{H}_{2}$ : Keadilan Prosedural berpengaruh positif terhadap Kepercayaan pada Otoritas Pajak

\section{Pengaruh Kepercayaan pada Otoritas Pajak terhadap Kepatuhan Pajak Sukarela}

Dalam teori slippery slope, kepercayaan pada otoritas pajak digambarkan akan meningkatkan kepatuhan pajak sukarela. Di sini lain, penggunaan kewenangan oleh otoritas pajak akan menimbulkan kepatuhan pajak dipaksakan (enforced tax compliance). Hal ini dijelaskan oleh konsep moral bahwa orang yang percaya akan cenderung patuh, sekalipun tidak ada tindakan dari otoritas. Secara empiris, teori tersebut didukung bukti yang dihasilkan dari penelitian Kirchler et al. (2008), Van Dijke dan Verboon (2010), Ratmono (2014), Gobena dan Van Dijke (2015) dan Hakim et al. (2017) yang menemukan bahwa kepercayaan (trust) terhadap otoritas pajak merupakan variabel determinan penting untuk kepatuhan pajak sukarela. Wajib pajak cenderung enggan membayar dan menjadi tidak patuh ketika mengetahui pajak yang mereka bayarkan diselewengkan atau tidak dikelola dengan baik, demikian juga sebaliknya. Sehingga rumusan hipotesisnya adalah sebagai berikut:

$\mathrm{H}_{3}$ : Kepercayaan pada Otoritas Pajak berpengaruh positif terhadap Kepatuhan Pajak Sukarela

\section{Pengaruh Denda Pajak terhadap Kepatuhan Pajak Sukarela}

Menurut teori slippery slope, denda dapat dipersepsikan sebagai balasan (retribution) yang tepat dari otoritas bagi perilaku yang membahayakan masyarakat. Pemberian sanksi yang lebih berat cenderung dipersepsikan retributive daripada sanksi yang ringan. Sanksi yang berat cenderung efektif dalam meningkatkan kepatuhan wajib pajak karena muncul sebagai sinyal ketidaksetujuan moral terhadap pelanggaran pajak. Penelitian yang dilakukan Mulder et al (2006) menguji dan menemukan pengaruh denda pajak terhadap kepatuhan pajak sukarela. Denda pajak yang berat merupakan sinyal bahwa keputusan otoritas pajak telah mewakili ketidaksetujuan moral masyarakat terhadap pelanggaran pajak. Berdasarkan uraian di atas maka disusun hipotesis sebagai berikut:

\section{$\mathrm{H}_{4}$ : Denda Pajak berpengaruh positif terhadap Kepatuhan Pajak Sukarela}

\section{Pengaruh Keadilan Prosedural terhadap Kepatuhan Pajak Sukarela \\ Fairness Heuristic Theory antara lain menjelaskan tentang kolektivitas/ keanggotaan sosial yang didorong orang perasaan memiliki (sense of belonging). Seseorang akan merasa}


memiliki dan memberikan kontribusi jika keberadaannya memperoleh pengakuan. Perlakuan setara yang termaktub dalam keadilan prosedural oleh karenanya dipandang mampu membuat masyarakat menjadi patuh, termasuk dalam memenuhi kewajiban perpajakannya. Hasil penelitian Murphy (2014) sejalan dan mengkonfirmasi teori tersebut di atas. Studi empirisnya membuktikan bahwa prosedur yang adil tanpa memperhatikan adanya kepentingan khusus dapat menimbulkan kolektivitas/keanggotaan sosial. Selanjutnya masyarakat akan cenderung berkontribusi antara lain dengan mematuhi peraturan dan norma sosial yang berlaku termasuk peraturan perpajakan. Berdasarkan hal tersebut, dirumuskan hipotesis sebagai berikut

$\mathrm{H}_{5}$ : Keadilan Prosedural berpengaruh positif terhadap Kepatuhan Pajak Sukarela

\section{Pengaruh Denda Pajak dengan Dimediasi Kepercayaan pada Otoritas Pajak terhadap Kepatuhan Pajak Sukarela}

Denda pajak dapat dilihat dari dua perspektif yaitu perspektif compensatory dan retributive (Mulder et al, 2006). Perspektif compensatory melihat denda pajak semata sebagai sebuah transaksi ekonomi. Sedangkan perspektif retributive menunjukkan denda pajak dalam perspektif yang lebih luas yaitu sebagai sebuah hukuman atas sebuah ketidakpatuhan moral. Denda pajak cenderung bersifat retributive ketika wajib pajak memiliki kepercayaan pada otoritas perpajakan. Dengan keberadaan aspek moral, wajib pajak akan merasa bersalah ketika dikenakan denda pajak, sehingga selanjutnya akan cenderung percaya terhadap otoritas dan menciptakan kepatuhan pajak sukarela. Argumen tersebut terkonfirmasi terbukti secara empiris berdasarkan penelitian yang dilakukan Ratmono (2014) yang menemukan bahwa kepercayaan pada otoritas pajak memediasi denda pajak dan kepatuhan pajak sukarela. Denda pajak merupakan trigger yang menimbulkan perasaan bahwa otoritas pajak hadir sekaligus dapat dipercaya, dan selanjutnya membangkitkan komitmen moral wajib pajak untuk menjadi patuh di kemudian hari tanpa harus mendapatkan denda kembali. Hipotesisnya adalah:

$\mathrm{H}_{6}$ : Denda Pajak dengan Dimediasi Kepercayaan pada Otoritas Pajak berpengaruh positif terhadap Kepatuhan Pajak Sukarela

\section{Pengaruh Keadilan Prosedural dengan Dimediasi Kepercayaan pada Otoritas Pajak terhadap Kepatuhan Pajak Sukarela}

Teori fairness heuristic menjelaskan hubungan antara keadilan prosedural, kepercayaan pada otoritas pajak, dan kepatuhan pajak sukarela. Fairness heuristic dalam konteks perpajakan muncul ketika dirasa memberikan perlakuan adil, otoritas pajak cenderung akan dipercaya, dan selanjutnya masyarakat tidak akan keberatan untuk berinventasi lebih jauh dengan menjadi patuh dan membayar pajak sesuai ketentuan. Hasil penelitian Murphy (2004) menunjukkan bahwa kepercayaan pada otoritas pajak juga memediasi pengaruh keadilan prosedural terhadap kepatuhan pajak. Penelitian yang dilakukan berikutnya yaitu Van Dijke dan Verboon (2010), Ratmono (2014), Gobena dan Van Dijke (2015) dan Hakim et al. (2017) juga mendukung argumen tersebut di atas. Kepercayaan pada otoritas pajak merupakan kata kunci untuk mewujudkan kepatuhan pajak sukarela, di mana kepercayaan tersebut terbentuk jika otoritas pajak berlaku adil. Oleh karena itu, hipotesis disusun sebagai berikut:

$\mathrm{H}_{7}$ : Keadilan Prosedural dengan Dimediasi Kepercayaan pada Otoritas Pajak berpengaruh positif terhadap Kepatuhan Pajak Sukarela

\section{Metode Penelitian \\ Jenis Penelitian}

Jenis penelitian adalah metode kuantitatif. Berdasarkan hubungan antara variabel yang diteliti, maka penelitian ini merupakan penelitian asosiatif kausal yaitu hubungan yang bersifat sebab-akibat. Jadi penelitian ini akan menganalisis pengaruh variabel independen yaitu denda 
pajak $\left(\mathrm{X}_{1}\right)$, keadilan prosedural $\left(\mathrm{X}_{2}\right)$, melalui variabel pemediasi yaitu kepercayaan pada otoritas pajak (M) terhadap variabel dependen yaitu kepatuhan pajak sukarela (Y).

\section{Populasi, Sampel, Besar Sampel, dan Teknik Pengambilan Sampel}

Populasi dalam penelitian ini adalah wajib pajak orang pribadi nonkaryawan yang terdaftar dan wajib menyampaikan SPT Tahunan di KPP Pratama Manado per tanggal 31 Desember 2018 sebanyak 16.852 wajib pajak. Sampel dari penelitian ini ditetapkan minimal sebesar 100 wajib pajak orang pribadi nonkaryawan. Jumlah sampel ditetapkan berdasarkan pendapat Hair (1998) yang menganjurkan sampel di atas 30, dan sampel sekitar 100 dianggap memadai. Penentuan sampel menggunakan prosedur sampling nonprobabilitas dengan teknik sampling kuota.

\section{Prosedur Pengumpulan Data}

Berdasarkan settingnya, penelitian ini merupakan metode penelitian survei di mana data diperoleh pada setting alamiah (natural setting) yaitu pada Kantor Pelayanan Pajak Pratama Manado. Dilihat dari sumber data, penelitian ini menggunakan sumber data primer. Berdasarkan cara atau teknik pengumpulan data, penelitian ini menggunakan kuesioner.

\section{Teknik Analisis Data}

Analisis terhadap data yang diperoleh dari survei kuesioner akan menggunakan Structural Equation Modeling (SEM) karena model teoritis penelitian ini menggunakan variabel-variabel yang tidak bisa diukur secara langsung (unobserved variables) atau disebut konstruk. Analisis dilakukan dengan bantuan software AMOS 24 dengan tahapan, uji validitas dan reliabilitas konstruk, dan uji hipotesis. Namun sebelumnya dilakukan analisis statistik deskriptif menggunakan SPSS. Uji mediasi dilakukan dengan persamaan regresi model jalur.

\section{Hasil Penelitian}

Analisis ini untuk mengetahui deskripsi data variabel seperti mean, nilai minimum, nilai maksimum, dan standar deviasi. Statistik deskriptif tentang variabel-variabel penelitian sebagai berikut:

\begin{tabular}{|l|l|r|r|r|r|}
\hline & $\mathrm{N}$ & Minimum & Maximum & Mean & Std. Deviation \\
\hline Denda pajak $\left(\mathrm{X}_{1}\right)$ & 106 & 4 & 10 & 6.81 & 1.360 \\
Keadilan Prosedural $\left(\mathrm{X}_{2}\right)$ & 106 & 9 & 19 & 14.42 & 2.715 \\
Kepercayaan pada otoritas pajak (M) & 106 & 3 & 15 & 11.66 & 3.372 \\
Kepatuhan Pajak Sukarela (Y) & 106 & 6 & 15 & 11.85 & 2.821 \\
Valid N (listwise) & 106 & & & & \\
\hline
\end{tabular}

Sumber: Data diolah, 2019

\section{Uji Confirmatory Factor Analysis (CFA)}

Uji CFA atau uji validitas konstruk dimaksudkan untuk mengetahui apakah setiap indikator dapat menjelaskan konstruk yang ada. Menurut Ghozali (2016) yang pertama dilihat adalah nilai signifikansi ( $P$ value), jika $P$ value lebih dari 0,05 maka indikator dieliminasi dari model. Ke dua adalah melihat nilai standardized loading factor (nilai Estimate). Ghozali (2016) menambahkan jika nilai Estimate di bawah 0,50 maka indikator dieliminasi karena dianggap tidak valid mengukur konstruk latennya. Hasil pengujian tersebut menunjukkan seluruh indikator dalam penelitian ini dapat menjelaskan konstruk atau variabel. 


\section{Uji Reliabilitas}

Uji reliabilitas dilakukan untuk mengukur konsistensi indikator-indikator dalam variabel laten. Uji reliabilitas dalam penelitian ini menggunakan construct reliability $(\mathrm{CR})$ dan persentase rata-rata nilai variance extracted (AVE). Ghozali (2016) menyebutkan bahwa CR 0.70 atau lebih menunjukkan reliabilitas yang baik. Meskipun nilai CR 0.60 sampai dengan 0.70 masih dapat diterima. Sedangkan kriteria AVE ditetapkan harus lebih dari 0.50. Hasil penelitian menunjukkan nilai CR keempat variabel lebih dari 0,60. Bahkan tiga variabel di antaranya bernilai lebih dari 0,70. Sedangkan AVE keempat variabel menunjukkan nilai lebih dari 0,50. Hal ini berarti keempat variabel memiliki reliabilitas yang baik dan dapat diterima.

\section{Uji Kelayakan Model (Goodness of Fit)}

Menilai goodness of fit merupakan tujuan utama dalam persamaan struktural yaitu untuk mengetahui seberapa jauh model fit atau cocok dengan sampel data. Banyak parameter yang digunakan untuk menilai goodness of fit, Haryono (2017) menyebutkan suatu model dinyatakan cocok dengan sampel data jika memenuhi sekurang-kurangnya 5 parameter goodness of fit.

Hasil uji goodness of fit tergambar dalam tabel sebagai berikut

\begin{tabular}{|l|c|c|l|}
\hline Parameter & Kriteria & Hasil & Kesimpulan \\
\hline Probabilitas Chi Square & $\geq 0,05$ & 0,068 & Fit \\
\hline CMIN/DF & $\leq 2,00$ & 1,319 & Fit \\
\hline CFI & $\geq 0,90$ & 0,976 & Fit \\
\hline TLI & $\geq 0,90$ & 0,967 & Fit \\
\hline NFI & $\geq 0,90$ & 0,911 & Fit \\
\hline IFI & $\geq 0,90$ & 0,977 & Fit \\
\hline RMSEA & $\leq 0,08$ & 0,055 & Fit \\
\hline
\end{tabular}

Sumber: Data diolah 2019

Hasil tersebut menunjukkan bahwa 7 (tujuh) parameter memenuhi kriteria, sehingga dapat disimpulkan secara keseluruhan model telah fit atau cocok dengan sampel data.

\section{Pengujian Hipotesis}

Pengujian hipotesis menggunakan estimasi model dengan melihat nilai P (Probabilitas). Santoso (2015) merumuskan dasar pengambilan keputusan jika nilai $\mathrm{P}$ (Probabilitas) $<0,05$ menunjukkan adanya pengaruh yang berarti $\mathrm{H}_{0}$ diterima dan $\mathrm{H}_{\mathrm{a}}$ ditolak. Sebaliknya jika nilai $\mathrm{P}$ (Probabilitas) $>0,05$, maka tidak terdapat pengaruh atau $\mathrm{H}_{0}$ ditolak dan $\mathrm{H}_{\mathrm{a}}$ diterima. Tujuh hipotesis yang diuji dalam penelitian ini adalah sebagai berikut:

\begin{tabular}{|l|l|l|l|}
\hline \multicolumn{2}{|c|}{ Hipotesis } & \multicolumn{1}{c|}{$\mathrm{P}$} & \multicolumn{1}{c|}{ Kesimpulan } \\
\hline $\mathrm{H}_{1}$ & $\mathrm{X}_{1} \rightarrow \mathrm{M}$ & .564 & Hipotesis ditolak \\
$\mathrm{H}_{2}$ & $\mathrm{X}_{2} \rightarrow \mathrm{M}$ & .030 & Hipotesis diterima \\
$\mathrm{H}_{3}$ & $\mathrm{M} \rightarrow \mathrm{Y}$ & .044 & Hipotesis diterima \\
$\mathrm{H}_{4}$ & $\mathrm{X}_{1} \rightarrow \mathrm{Y}$ & .982 & Hipotesis ditolak \\
$\mathrm{H}_{5}$ & $\mathrm{X}_{2} \rightarrow \mathrm{Y}$ & .141 & Hipotesis ditolak \\
\hline
\end{tabular}

Sumber: Output AMOS, diolah 2019 
Pengujian hipotesis $\mathrm{H}_{6}$ dan $\mathrm{H}_{7}$ dilakukan dengan uji mediasi karena melibatkan variabel pemediasi. Uji mediasi dilakukan dengan membandingkan dan menganalisis besarnya koefisien pengaruh langsung, tidak langsung dan total sehingga dapat diketahui apakah variabel mediasi memediasi pengaruh variabel independen.

Hasil penelitian menunjukkan bahwa variabel $\mathrm{X}_{1}$ tidak signifikan terhadap $\mathrm{M}$ dan variabel $M$ signifikan terhadap $Y$. Sehingga dapat disimpulkan bahwa $M$ tidak memediasi pengaruh antara $\mathrm{X}_{1}$ terhadap $\mathrm{Y}$. Hal ini berarti hipotesis $\left(\mathrm{H}_{6}\right)$ bahwa Denda Pajak dengan Dimediasi Kepercayaan pada Otoritas Pajak berpengaruh positif terhadap Kepatuhan Pajak Sukarela ditolak. Hasil penelitian juga menunjukkan variabel $\mathrm{X}_{2}$ signifikan terhadap $\mathrm{M}$, dan variabel $\mathrm{M}$ signifikan terhadap $\mathrm{Y}$. Hal ini berarti $\mathrm{M}$ memediasi pengaruh antara $\mathrm{X}_{2}$ terhadap $\mathrm{Y}$. Sehingga hipotesis $\mathrm{H}_{7}$ Keadilan Prosedural dengan Dimediasi Kepercayaan pada Otoritas Pajak berpengaruh positif terhadap Kepatuhan Pajak Sukarela diterima.

\section{Pembahasan}

Pengaruh Denda Pajak terhadap Kepercayaan pada Otoritas Pajak

Hasil pengujian hipotesis pertama, nilai probalibitas (P) sebesar 0,564 atau $>0,05$ sehingga menunjukkan bahwa denda pajak tidak berpengaruh positif terhadap kepercayaan pada otoritas pajak. Hasil penelitian ini tidak mendukung hasil penelitian Ratmono (2014) yang menemukan bukti empiris bahwa denda pajak berpengaruh positif dan signifikan terhadap kepercayaan pada otoritas pajak. Temuan ini menunjukkan bahwa responden dalam penelitian cenderung melihat denda dalam perspektif instrumental di mana denda tidak dilihat sebagai bukti kehadiran otoritas pajak, melainkan hanya sebagai transaksi ekonomi belaka. Besaran denda yang relatif kecil turut memberikan motif kepada wajib pajak untuk tidak menyampaikan SPT sesuai batas waktu karena keuntungan yang diperoleh lebih besar dibandingkan denda. Allingham dan Sandmo (1972) serta Carroll (1978) melihat bahwa agar efektif denda harus lebih besar daripada keuntungan yang diperoleh dari melakukan pelanggaran dengan harapan denda tidak hanya dlihat dari perspektif instrumental.

\section{Pengaruh Keadilan Prosedural terhadap Kepercayaan pada Otoritas Pajak}

Berdasarkan hasil estimasi model penelitian, diketahui keadilan prosedural memiliki pengaruh positif yang signifikan terhadap Kepercayaan pada Otoritas Pajak. Hasil penelitian ini sejalan dengan hasil yang ditemukan oleh Van Dijke dan Verboon (2010), Ratmono (2014), Gobena dan Van Dijke (2015), dan Hakim et al. (2017). Penelitian-penelitian tersebut menemukan bukti empiris bahwa Keadilan Prosedural berpengaruh signifikan terhadap Kepercayaan pada Otoritas Pajak. Temuan penelitian ini juga meneguhkan teori fairness heuristic yang disampaikan Lind (2001). Ketika otoritas pajak telah memperlakukan wajib pajak dengan sama dan setara, wajib pajak cenderung akan mempercayai otoritas pajak.

\section{Pengaruh Kepercayaan pada Otoritas Pajak terhadap Kepatuhan Pajak Sukarela}

Pengaruh Kepercayaan pada Otoritas Pajak terhadap Kepatuhan Pajak Sukarela tergambar dari nilai probabilitas $(\mathrm{P})$ hasil estimasi model sebesar 0,044 yang berarti Kepercayaan pada Otoritas Pajak berpengaruh positif dan signifikan terhadap Kepatuhan Pajak Sukarela. Hasil penelitian mendukung temuan penelitian-penelitian sebelumnya antara lain Kastlunger et al. (2013), Kogler et al.(2013), Ratmono (2014) dan Hakim et al. (2017). Penelitian ini memberikan tambahan bukti empiris bahwa otoritas pajak yang dapat dipercaya akan meningkatkan kepatuhan wajib pajak dalam memenuhi kewajiban perpajakan secara sukarela. Dalam perspektif good corporate governance, otoritas yang transparan dan akuntabel akan menimbulkan kepercayaan masyarakat. Selanjutnya berdasarkan kepercayaan tersebut, partisipasi dan keterlibatan masyarakat akan meningkat. Lind (2001) menyampaikan terkait 
tingkat investasi sosial, bahwa masyarakat yang percaya dengan otoritas akan rela berperan lebih, termasuk dalam hal ini menjadi wajib pajak yang patuh.

\section{Pengaruh Denda Pajak terhadap Kepatuhan Pajak Sukarela}

Hasil pengujian $\mathrm{H}_{04}$ dalam penelitian ini yang menyatakan bahwa denda pajak berpengaruh positif terhadap kepatuhan pajak sukarela ditolak. Hal ini dibuktikan dengan nilai probalibitas (P) sebesar 0,982 atau >0,05. Hasil penelitian ini berbeda dengan temuan Cahyonowati (2011) yang menyatakan denda pajak berpengaruh positif terhadap kepatuhan pajak, meskipun dalam penelitian tersebut tidak dipisahkan antara kepatuhan pajak sukarela dan kepatuhan pajak dipaksakan. Namun demikian hasil ini mendukung temuan penelitian Ratmono (2014) yang menemukan bukti empiris bahwa denda pajak dan kepatuhan pajak sukarela tidak memiliki pengaruh langsung. Temuan penelitian ini dapat menjelaskan temuan Wenzel (2004) bahwa sanksi berpengaruh terhadap kepatuhan untuk masyarakat yang percaya bahwa membayar pajak merupakan sebuah perilaku etis. Artinya terdapat prasyarat yang membuat denda pajak mempengaruhi kepatuhan pajak sukarela, yaitu kesadaran wajib pajak bahwa kepatuhan merupakan sebuah perilaku etis. Dalam penelitian ini dimensi etis cenderung tidak lebih dominan dibandingkan dimensi ekonomi dalam konteks wajib pajak memperlakukan denda pajak.

\section{Pengaruh Keadilan Prosedural terhadap Kepatuhan Pajak Sukarela}

Berdasarkan hasil estimasi model penelitian, diketahui keadilan prosedural tidak memiliki pengaruh positif terhadap kepatuhan pajak sukarela. Hal ini berarti $\mathrm{H}_{05}$ tidak terbukti karena nilai probabilitas $(\mathrm{P})$ sebesar 0,141, atau >0,05. Dengan hasil tersebut dapat disimpulkan bahwa semakin tinggi keadilan prosedural tidak berarti semakin meningkatkan kepatuhan pajak sukarela. Hasil penelitian ini tidak sejalan dengan penelitian Murphy (2004). Penelitian Murphy (2004) menemukan bahwa keadilan memiliki pengaruh terhadap kepatuhan. Namun penelitian ini mengkonfirmasi hasil penelitian Ratmono (2014) yang menemukan bukti empiris bahwa keadilan prosedural dan kepatuhan pajak sukarela tidak memiliki pengaruh langsung. Pada gilirannya diketahui bahwa pengaruh keadilan prosedural dan kepatuhan pajak sukarela dimediasi dengan kepercayaan pada otoritas pajak. Hal ini juga menguatkan teori fairness heuristic (Lind, 2001). Teori ini menunjukkan masyarakat menggunakan judgement mereka tentang keadilan prosedural sebagai sebuah panduan sederhana (heuristic guide) untuk menilai apakah otoritas akan menyalahgunakan wewenangnya serta apakah otoritas dapat dipercaya sebagai proxy untuk memberikan kontribusi lanjutan antara lain dengan menjadi patuh secara sukarela terdahap ketentuan perpajakan. Artinya keberadaan kepercayaan pada otoritas pajak merupakan prasyarat mutlak untuk menjelaskan hubungan keadilan prosedural dan kepatuhan pajak sukarela.

\section{Pengaruh Denda Pajak terhadap Kepatuhan Pajak Sukarela dengan Dimediasi Kepercayaan pada Otoritas Pajak}

Uji mediasi menunjukkan hasil bahwa Denda Pajak tidak signifikan terhadap Kepercayaan pada Otoritas Pajak dan Kepercayaan pada Otoritas Pajak signifikan terhadap Kepatuhan Pajak Sukarela. Sehingga dapat disimpulkan bahwa Kepercayaan pada Otoritas Pajak tidak memediasi pengaruh antara Denda Pajak terhadap Kepatuhan Pajak Sukarela. Hal ini berarti hipotesis $\left(\mathrm{H}_{06}\right)$ bahwa Denda Pajak dengan Dimediasi Kepercayaan pada Otoritas Pajak berpengaruh positif pada Kepatuhan Pajak Sukarela ditolak.

Hasil penelitian ini tidak mendukung hasil penelitian Ratmono (2014) yang menemukan bukti empiris bahwa Kepercayaan pada Otoritas Pajak mampu memediasi Denda Pajak dengan Kepatuhan Pajak Sukarela. Temuan Ratmono (2014) menunjukkan bahwa pemberian denda pajak tidak dapat langsung meningkatkan kepatuhan pajak sukarela namun 
denda dapat mempengaruhi kepercayaan pada otoritas pajak baru kemudian mempengaruhi kepatuhan pajak sukarela. Tidak terbuktinya hipotesis mengindikasikan secara umum wajib pajak tidak mempersepsikan denda pajak secara retributive sebagai balasan yang tepat sekaligus bukti kehadiran otoritas pajak (Mulder et al, 2006).

\section{Pengaruh Keadilan Prosedural terhadap Kepatuhan Pajak Sukarela dengan Dimediasi Kepercayaan pada Otoritas Pajak}

Hasil uji mediasi menunjukkan variabel Keadilan Prosedural signifikan terhadap Kepercayaan pada Otoritas Pajak, dan variabel Kepercayaan pada Otoritas Pajak signifikan terhadap Kepatuhan Pajak Sukarela. Hal ini berarti Kepercayaan pada Otoritas Pajak memediasi pengaruh antara Keadilan Prosedural terhadap Kepatuhan Pajak Sukarela. Sehingga hipotesis $\mathrm{H}_{07}$ Keadilan Prosedural dengan Dimediasi Kepercayaan pada Otoritas Pajak berpengaruh positif terhadap Kepatuhan Pajak Sukarela diterima.

Bukti empiris penelitian ini mendukung hasil penelitian sebelumnya oleh Van Dijke dan Verboon (2010), Ratmono (2014), Gobena dan Van Dijke (2015), dan Hakim et al. (2017). Penelitian tersebut menemukan bahwa kepercayaan pada otoritas pajak memediasi pengaruh keadilan prosedural terhadap kepatuhan pajak sukarela. Teori fairness heuristic yang dikemukakan Lind (2001) antara lain menyebut prosedur yang dianggap adil oleh wajib pajak dapat meningkatkan kepercayaan wajib pajak pada otoritas pajak dan selanjutnya meningkatkan kepatuhan pajak sukarela. Otoritas pajak yang berlaku adil, bertanggung jawab, dan penuh hormat kepada wajib pajak akan mendorong terciptanya iklim sinergistik di mana hubungan antara otoritas pajak dengan wajib pajak seperti pemberi jasa dan klien (serviceclient). Wajib pajak (klien) yang diperlakukan adil cenderung mempercayai otoritas pajak sebagai pemberi jasa, dan selanjutnya berbekal kepercayaan tersebut wajib pajak akan secara sukarela mematuhi ketentuan yang berlaku di bidang perpajakan.

\section{Kesimpulan}

Berdasarkan uji statistik yang dilakukan, diperoleh hasil sebagai berikut:

1. denda pajak $\left(X_{1}\right)$ tidak berpengaruh positif terhadap kepercayaan pada otoritas pajak $(M)$, sehingga $\mathrm{H}_{01}$ ditolak;

2. keadilan prosedural $\left(\mathrm{X}_{2}\right)$ berpengaruh positif dan signifikan terhadap kepercayaan pada otoritas pajak (M), sehingga $\mathrm{H}_{02}$ diterima;

3. kepercayaan pada otoritas pajak $(\mathrm{M})$ berpengaruh positif dan signifikan terhadap kepatuhan pajak sukarela (Y), sehingga $\mathrm{H}_{03}$ diterima;

4. denda pajak $\left(\mathrm{X}_{1}\right)$ tidak berpengaruh positif terhadap kepatuhan pajak sukarela (Y), sehingga $\mathrm{H}_{04}$ ditolak;

5. keadilan prosedural $\left(\mathrm{X}_{2}\right)$ tidak berpengaruh positif terhadap kepatuhan pajak sukarela $(\mathrm{Y})$, sehingga $\mathrm{H}_{05}$ ditolak;

6. uji mediasi menunjukkan hasil bahwa Denda Pajak tidak signifikan terhadap Kepercayaan pada Otoritas Pajak dan Kepercayaan pada Otoritas Pajak signifikan terhadap Kepatuhan Pajak Sukarela. Sehingga dapat disimpulkan bahwa Kepercayaan pada Otoritas Pajak tidak memediasi pengaruh positif antara Denda Pajak terhadap Kepatuhan Pajak Sukarela. Hal ini berarti hipotesis $\left(\mathrm{H}_{06}\right)$ ditolak.

7. hasil uji mediasi menunjukkan variabel Keadilan Prosedural signifikan terhadap Kepercayaan pada Otoritas Pajak, dan variabel Kepercayaan pada Otoritas Pajak signifikan terhadap Kepatuhan Pajak Sukarela. Hal ini berarti Kepercayaan pada Otoritas Pajak memediasi pengaruh positif antara Keadilan Prosedural terhadap Kepatuhan Pajak Sukarela sehingga hipotesis $\mathrm{H}_{07}$ diterima. 


\section{Saran}

Berdasarkan hasil penelitian dan kesimpulan berdasarkan bukti empiris, berikut ini disampaikan saran dalam rangka meningkatkan kepatuhan pajak sukarela sebagai berikut:

1. Bagi otoritas pajak dalam hal ini KPP Pratama Manado agar meningkatkan kepercayaan wajib pajak pada otoritas pajak. Kepercayaan wajib pajak antara lain dapat ditimbulkan dan ditingkatkan dengan pelayanan dan tindakan pengawasan yang adil dan setara, termasuk memberikan ruang bagi wajib pajak untuk berpartisipasi. Upaya serius untuk memastikan seluruh aktivitas yang dilakukan dalam administrasi perpajakan terbebas dari korupsi dan/atau tindakan lain yang dapat mencederai kepercayaan wajib pajak juga sebaiknya dilakukan secara kontinu. Edukasi dan penyuluhan yang mengena dan tepat sasaran juga dipercaya dapat meningkatkan kepercayaan wajib pajak yang pada akhirnya mampu meningkatkan kepatuhan sukarela wajib pajak;

2. Dengan ditolaknya beberapa hipotesis menunjukkan bahwa model kepatuhan pajak sukarela yang dikembangkan Ratmono (2014) membutuhkan penelitian lanjutan dalam rangka validasi model. Penelitian lanjutan juga diperlukan untuk mengetahui determinan keadilan prosedural yang berdasarkan bukti empiris dapat meningkatkan kepercayaan wajib pajak terhadap otoritas pajak.

\section{DAFTAR PUSTAKA}

Allingham, M.G., and A. Sandmo. 1972. Income Tax Evasion: A Theoritical Analysis. Journal of Public Economics 1 (3): 323-338

Alm, J., I. Sanchez, and A. de Juan. 1995. Economic and Noneconomic Factors in Tax Compliance. Kyklos 48: 1-18.

Cahyonowati, N. 2011. Model Moral dan Kepatuhan Perpajakan: Wajib Pajak Orang Pribadi. Jurnal Akuntansi dan Auditing Indonesia 161-177

Cahyonowati, N., D. Ratmono, dan Faisal. 2012. Peranan Etika, Pemeriksaan, dan Denda Pajak Untuk Meningkatkan Kepatuhan Wajib Pajak Orang Pribadi. Jurnal Akuntansi dan Keuangan Indonesia 9 (2): 136-153

Carroll, J.S. 1978. A Psychological Approach to Deterrence: The Evaluation of Crime Opportunities. Journal of Personality and Social Psychology 36 (12): 1512-1520

Fajriyan, N.A., M.G. Endang, dan A. Prasetya. 2015. Pengaruh Persepsi Pelaksanaan Sensus Pajak Nasional, Sikap Wajib Pajak pada Pelaksanaan Sanksi Denda dan Kesadaran Perpajakan Terhadap Kepatuhan Wajib Pajak (Studi pada Wajib Pajak Orang Pribadi di Kelurahan Mijil Kota Mojokerto). Jurnal Perpajakan 1 (1): 1-9

Ghozali, Imam. 2016. Model Persamaan Struktural Konsep dan Aplikasi dengan Program AMOS 24 Update Bayesian SEM. Semarang: Badan Penerbit Undip

Gobena, L.B., and M. Van Dijke. 2015. Power, Justice, and Trust: A Moderated Mediation Analysis of Tax Compliance among Ethiopian Business Owners. Journal of Economic Psychology

Hair, J. F. 1998. Multivariate Data Analysis. Fifth Edition, International Edition. Prentice Hall.

Hakim, Z., L. Handajani, dan B.A. Inapty. 2017. Voluntary Tax Compliance Wajib Pajak Perusahaan Perhotelan: Determinan, Kepercayaan dan Kekuasaan Legitimasi. Jurnal Akuntansi 21 (02): 253-277

Haryono, Siswoyo. 2017. Metode SEM Untuk Penelitian Manajemen dengan AMOS Lisrel PLS. Jakarta: Luxima Metro Media

Kalangi, L. 2014. Pengaruh Tarif Pajak dan Probabilitas Audit Terhadap Kepatuhan Pajak Penghasilan (Studi Eksperimen Laboratorium). Jurnal Riset Akuntansi dan Auditing Goodwill 5 (1): 20-29 
Kastlunger, B., E. Lozza, E. Kirchler, and A. Schabmann. 2013. Powerful Authorities and Trusting Citizens: The Slippery Slope Framework and Tax Compliance in Italy. Journal of Economic Psychology 34 (2013): 36-45

Kirchler, E., E. Hoelzl, and I. Wahl. 2008. Enforced Versus Voluntary Tax Compliance: The Slippery Slope Framework. Journal of Economic Psychology 29 (2): 210-225

Kogler, C., L. Batrancea, A. Nichita, J. Pantya, A. Belianin, and E. Kirchler. 2013. Trust and Power as Determinants of Tax Compliance: Testing the Assumptions of the Slippery Slop Framework in Austria, Hungary, Romania and Russia. Journal of Economic Pshychology 34 (1): 169-180

Konovsky, M. A., and R. Cropanzano. 1991. Perceived Fairness of Employee Drug Testing as A Predictor of Employee Attitudes and Job Performance. Journal of Applied Psychology 76 (5): 698-707

Korsgaard, M. A., D. M. Cchweiger, and H. J. Sapienza. 1995. Building Commitment, Attachment, and Trust in Strategic Decision-Making Teams: The Role of Procedural Justice. Academy of Management Journal 38 (1): 60-84

Lind, E. A. 2001. Fairness Heuristic Theory: Justice Judgements as Pivotal Cognitions in Organizational Realtions. In Advances in Organizational Justice edited by $\mathrm{J}$ Greenberg dan R Cropanzano. Stanford, USA: Stanford University Press

MacKinnon, David. 2008. Introduction to Statistical Mediation Analysis. New York: Taylor \& Francis Group, LLC

Mulder, L. B., E. Van Dijk, D. De Cremer, and H. A. M. Wile. 2006. Undermining Trust and Cooperation: The Paradox of Sanctioning System in Social Dilemmas. Journal or Experimental Social Psychology 42: 147-162

Murphy, K. 2004. The Role of Trust in Nurturing Compliance: A Study of Accused Tax Avioders. Law and Human Behavior 28 (2): 187-209

Nurmantu, S. 2000. Dasar-dasar Perpajakan. Jakarta. Ind-Hill-Co

Ratmono, D. 2014. Model Kepatuhan Perpajakan Sukarela: Peran Denda, Keadilan Prosedural, dan Kepercayaan pada otoritas pajak. Jurnal Akuntansi dan Auditing Indonesia 18 (1): 42-64

Riduwan dan Akdon. 2013. Rumus dan Data Dalam Analisis Statistika. Bandung: Alfabeta

Santoso, Singgih. 2015. AMOS 22 untuk Structural Equation Modeling. Jakarta: PT Elex Media Komputindo

Sugiyono. 2017. Metode Penelitian Kuantitatif, Kualitatif, dan R \& D. Bandung: Alfabeta

Thibaut, J. W., and L. Walker. 1975. Procedural Justice: A Psychological Analysis. Hillsdale: Lawrance Erlbaum

Tyler, T. R. 1997. The Psychology of Legitimacy: A Relational Perspective on Voluntary Deference to Authoriries. Personality and Social Psychology Review 1(4): 323-345

Van Dijke, M. and P. Verboon. 2010. Trust in Authorities as a Boundary Condition to Procedural Fairness Effects on Tax Compliance. Journal of Economis Psychology 31 (1): 80-91

Wenzel, M. 2004. The Social Side of Sanctions: Personal and Social Norms as Moderators of Deterrence. Law and Human Behavior 28 (5): 547-567 